\title{
Conhecimento de acadêmicos de Enfermagem frente à parada cardiorrespiratória
}

\section{Knowledge of nursing students face to cardiorespiratory arrest}

\author{
Juliana Araújo Pereira Gomes ${ }^{1}$ \\ Márcia Ribeiro Braz ${ }^{2}$
}

Palavras-chave:

Ensino em

Enfermagem

Grade curricular

Parada

cardiopulmonar

Ressuscitação

Cardiopulmonar
Resumo:

Vítimas que sofrem uma parada cardíaca e ficam sem assistência adequada por mais de 3 minutos podem evoluir para um prognóstico ruim, chegando até a morte. A reanimação cardiopulmonar é um conjunto de procedimentos que aprendemos durante a graduação em enfermagem, porém, não é muito aprofundado o tema durante as aulas, devido à especificidade da grade curricular, que aponta para um curso generalista. Este estudo propõe como objetivo identificar o conhecimento de acadêmicos graduandos em enfermagem sobre a atuação do enfermeiro em casos de parada cardiorrespiratória. Trata-se de uma pesquisa de natureza qualitativa descritiva e contou com a participação de acadêmicos de um Curso em Enfermagem da região serrana do Rio de Janeiro, sendo utilizado um questionário estruturado para avaliação das manobras de ressuscitação cardiopulmonar. Concluímos que poucos discentes da Instituição pesquisada saberiam o que fazer diante de uma vítima de PCR, apesar de estarem próximos á a conclusão do curso. Observamos que, apesar do conteúdo teórico e prático sobre PCR ser oferecido em algumas disciplinas, ao final do curso, o discente ainda sai com essa lacuna em sua formação. $O$ futuro enfermeiro, ao sair da faculdade, deve estar apto a auxiliar e identificar problemas de saúde em situação de risco e fazer sucessivas reavaliações posteriores conforme as mudanças apresentadas no quadro do paciente, visando sempre rapidez e sincronismo com a equipe para uma melhor assistência prestar.

\section{Abstract}

It is known that victims who suffer cardiac arrest and who are left without adequate assistance for more than 3 minutes may evolve to bad prognosis progressing until the death. The cardiopulmonary reanimation is a set of procedures we learned during the undergraduate nursing, however, is not so depth the theme during the class, because of the curriculum specificity that indicate to a generalist course. The study aims to identify how the knowledge of nursing graduates on the role of nurses in cardiopulmonary arrest. It is a research of the descriptive qualitative nature, and counted with the participation of academics from a nursing Course in the mountainous region of Rio de Janeiro, and used a structured questionnaire to assess the cardiopulmonary resuscitation maneuvers. We conclude that few students researched the institution know what to do before a victim of cardiac arrest, despite being close to graduation. We note that despite the theoretical and practical content on PCR is offered in some disciplines, the end of the course, students still come out with this gap in their education. The future nurse, after completing college shall be able to help and identify health problems in risk situations and to make the successive revaluations in accordance with changes presented in the context of the patient, aiming to speed and synchronism with the team to provide a better assistance.

\section{Key words:}

Nursing education

Curriculum

Cardiopulmonary arrest

Cardiopulmonary

resuscitation
Artigo
Origina

Original

Paper

Recebido em 10/2011

Aprovado em $03 / 2012$

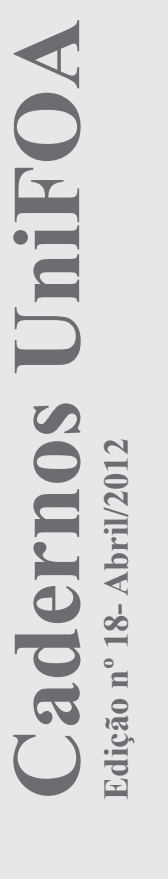

1 Faculdade Arthur Sá Earp Neto (FMP/FASE)

2 Faculdade Arthur Sá Earp Neto (FMP/FASE); Faculdade de Enfermagem de Valença (FEV/CESVA) 


\section{Introdução}

No campo de estágio, enquanto acadêmicas de enfermagem, ao presenciarmos uma parada cardiorrespiratória, vivenciamos um misto de sentimentos, em que o medo, a insegurança e a sensação de despreparo para atuar diante daquela situação despertaram nosso interesse nessa temática. Percebemos que o conhecimento teórico adquirido até o momento não era $o$ suficiente para que pudéssemos participar ativamente e com segurança nesta situação. A Parada Cardiorrespiratória (PCR), desde os primórdios da humanidade, segundo Bueno et al, (apud ZANINI et al 2006, p.144) é definida como "O súbito cessar da atividade miocárdica ventricular útil, associada à ausência de respiração", podendo ocorrer de forma abrupta e inesperada ocasionando ameaça à vida dos pacientes e, até mesmo, lesões irreversíveis por hipóxia cerebral.

Outros colegas do grupo demonstraram também sentir o mesmo que eu. Esse tema paralisa os acadêmicos de enfermagem pelo fato de imaginarmos que uma conduta incorreta pode custar à vida de um ser humano e que habilidade e raciocínio rápidos não são os únicos requisitos para uma intervenção eficaz, devendo assim, se fazer uma associação entre teoria e prática, que deve ser suficiente para atender uma vítima de PCR.

A reanimação cardiopulmonar (RCP) é um conjunto de procedimentos que aprendemos durante a graduação em enfermagem, porém, não é muito aprofundado o tema durante as aulas, devido à especificidade da grade curricular que aponta para um curso generalista. RCP consiste no tratamento da PCR. São manobras ou compressões que visam manter a circulação e respiração artificial e restaurá-las ao normal, o mais precoce possível, com intuito de reduzir a lesão cerebral. Com o propósito de manter um atendimento seguro, com rapidez e eficácia a PCR, ele é seguido através de uma abordagem de fases e algoritmos (FERREIRA JUNIOR, 2010).

Conforme as orientações da American Heart Association (ILCOR, 2011, p.86) O algoritmo de tratamento inicial do paciente visa ao reconhecimento da PCR e ao primeiro atendimento à vítima. Inicialmente, deve-se avaliar o estado de consciência do paciente; imediatamente após a detecção da inconsciência, chama-se por ajuda e realizam-se as manobras de desobstrução das vias aéreas e a procura de sinais de ausência de perfusão como: a inconsciência da vítima, inexistência de movimentos e a ausência de respiração.

No ano de 2009, com base em algoritmo, a conduta preconizada pelos profissionais da área de saúde para a realização da RCP, após acionarem uma equipe de suporte avançado e a solicitação de um desfibrilador, eram 2 ventilações de resgate, seguidas de 30 compressões torácicas. Esse ciclo se repetia por 5 vezes entre compressão e respiração ou até a chegada do desfibrilador. No entanto, ultimamente, constataram que a taxa de sobrevida pós PCR é três vezes maior em pessoas submetidas apenas à compressão torácica (FERREIRA JUNIOR, 2010).

Para Timerman, (apud FERREIRA JUNIOR, 2010, p.11) “O que era considerado um aliado no atendimento de emergência em caso de parada cardíaca, agora é visto como prejudicial". Fica então comprovado que a massagem cardíaca sozinha é mais eficaz na RCP. Essa mudança de conduta faz parte das novas diretrizes da ILCOR (Aliança Internacional dos Comitês de Ressuscitação), que passaram a valer em 2010, em todo o mundo.

Tendo em vista essa nova mudança no guideline, fica evidente que, para que a técnica seja executada de forma correta e baseada nos protocolos existentes, é necessário o conhecimento por parte da equipe de saúde, o que inclui o acadêmico de enfermagem.

A iniciativa para esse estudo veio a partir do olhar crítico que adquirimos na graduação, onde correlacionamos o conhecimento teórico com a prática vivenciada. Pelo fato da área de emergência ser muito ampla, abordar o preparo técnico-científico de acadêmicos de enfermagem frente à parada cardiorrespiratória se faz necessário para ampliar o conhecimento dos futuros enfermeiros, os quais poderão, em sua vida profissional, se defrontar com uma situação de PCR.

No âmbito hospitalar, a equipe de enfermagem, incluindo o acadêmico em seu campo de estágio, na maioria das vezes, é a primeira a presenciar uma PCR, pois permanece maior tempo com o paciente, em sua assistência integral. Segundo Moule (apud LIMA 2009, p.631), os profissionais necessitam ter conhecimento técnico atualizado e habilidades práticas desenvolvidas a fim de contribuírem, 
de forma mais efetiva, no reconhecimento dos sinais de uma PCR, assim como na realização das manobras tradicionais de RCP para que haja uma intervenção eficaz.

Diante da recente mudança no guideline de atendimento a PCR, nossa inquietação decorre do fato de não nos sentirmos preparadas, enquanto acadêmicas de enfermagem, para atuar em uma PCR, levando-nos ao aprofundamento deste conteúdo, configurando-se como objeto de estudo o aprendizado das manobras de ressuscitação cardiopulmonar na graduação de Enfermagem.

Para tanto, consideramos como questão norteadora: acadêmicos de enfermagem conseguem associar a teoria apreendida em sala de aula à prática, no que tange a PCR? Diante desse questionamento, o estudo propõe como objetivo identificar o conhecimento de acadêmicos de enfermagem sobre a atuação do enfermeiro diante de uma parada cardiorrespiratória.

Este estudo poderá proporcionar aos profissionais de saúde e acadêmicos de enfermagem conscientização sobre a necessidade de conhecimento atualizado no que tange as novas diretrizes da RCP, possibilitando uma ação sistematizada e resolutiva diante de uma PCR.

\section{Abordagem Metodológica}

Trata-se de uma pesquisa descritiva, exploratória, com abordagem qualitativa. $\mathrm{O}$ estudo foi realizado em uma instituição privada de ensino superior localizada na região serrana, que possui o curso de graduação em enfermagem.

Os sujeitos foram graduandos, cursando o $8^{\circ}$ período de enfermagem. Como critérios de exclusão da pesquisa, consideraram-se alunos que ainda não vivenciaram uma PCR e aqueles que já possuem a nível médio, o curso técnico de enfermagem. Devido a esses critérios, dos trinta e três alunos da turma, apenas quatro alunos, durante todo o curso, haviam vivenciado uma parada cardiorrespiratória durante o estágio e participaram da amostra. Segundo Figueiredo (2008 p. 97), "por se tratar de uma pesquisa de abordagem qualitativa, esta pesquisa produz grande quantidade de dados, dispensando a utilização de grandes amostras". O que torna viável o desenvolvimento deste estudo.
A coleta de dados se deu após a aprovação do Comitê de Ética em Pesquisa do Centro Universitário de Volta Redonda, através do CAAE: 0076.0.446.000-11. Considerando a Resolução 196/1996 do Conselho Nacional de Saúde (Brasil, 1997), os sujeitos deste estudo formalizaram a autorização e tomaram a ciência dos aspectos relativos às suas participações, mediante a explicação do pesquisador e assinatura após concordância do Termo de Consentimento Livre e Esclarecido (TCLE).

Como instrumento para a coleta de dados, foi utilizado questionário estruturado. Os questionários foram distribuídos após solicitação, por escrito, direcionada àInstituição que foi cenário desta pesquisa. Os dados foram tabulados inicialmente em planilha eletrônica Excel e, posteriormente, analisados por meio de estatística descritiva simples, sob a luz da literatura pertinente à temática.

\section{Resultados e Discussão}

O nível de conhecimento dos acadêmicos foi avaliado de acordo com seis perguntas acerca da temática. Quando questionado aos acadêmicos se saberiam agir se encontrassem uma pessoa desacordada e em PCR, apenas 25\% (1) dos entrevistados, disse que saberia como agir nessa situação. Os outros 75\% (3), não saberiam como agir, apesar de 100\% (04) dos entrevistados dizerem ter conhecimento do significado de uma PCR.

Para Capovilla (2002), na PCR, a atuação do enfermeiro na tomada de decisões rápidas e precisas é imprescindível para garantir o suporte básico de vida e a organização da equipe de atendimento. Isso reporta à necessidade de se repensar a formação acadêmica do enfermeiro, fundamentalmente em situações de emergência. As autoras op cit realizaram um estudo sobre conhecimentos de acadêmicos de enfermagem a respeito desta temática e os resultados apontaram para as dificuldades que os discentes possuem sobre PCR e RCP, principalmente em relação aos conhecimentos científicos que devem orientar suas ações. Desfibrilação, fármacos e ventilação em situações de PCR são os conteúdos em que os alunos enfrentam maiores dificuldades.

Cristina et al (2008, p.102), com relação à qualificação profissional em emergência, aborda que a Portaria do Ministério da Saúde 
2048/2002 (Ministério da Saúde, 2002) destaca a necessidade de treinamento voltado á melhoria da qualidade da informação referente á vigilância epidemiológica por causas externas. Nos cursos de graduação da área da saúde, a atenção na área de emergência é insuficiente, sendo necessária a complementação com cursos de formação, capacitação e educação permanente dos recursos humanos.

É sabido que uma PCR envolve muito além do que conhecimento científico do socorrista, também é necessário haver controle emocional da pessoa que vai prestar atendimento à vítima. Diante disso, Sasso e Souza (2006, p.34) afirmam que a tensão gerada em uma situação de PCR, muitas vezes, inibe e dificulta o desempenho profissional e a aprendizagem durante os procedimentos exigidos. Além disso, a dinâmica e a constante evolução do conhecimento científico e tecnológico requerem dos profissionais de saúde atualizações permanentes sobre as técnicas de RCP.

No que diz respeito à atuação em uma PCR, considerada uma grave emergência clínica, Silva et al (2010) afirma que a falta de conhecimento e habilidade dos profissionais envolvidos no atendimento à PCR, a falha na organização do atendimento, assim como provisão insuficiente de materiais e equipamentos necessários para realização das medidas de reanimação - favorecem a ocorrência de falhas no decorrer da assistência aos pacientes em PCR. O conhecimento e atualização quanto às recomendações das novas diretrizes da RCP são essenciais para reduzir a mortalidade associada a PCR.

Outros dados investigados foram o conhecimento dos graduandos sobre a reanimação cardiopulmonar e os sinais que identificam uma PCR. Aonde 50\% (2) desconhecem o que é a RCP e $50 \%$ (2) não sabem identificar uma pessoa em PCR. Esses dados apontam para uma lacuna na formação do enfermeiro. Em um estudo de Capovilla (2002) sobre o conhecimento de acadêmicos de enfermagem acerca de PCR/RCP, observou-se que os discentes apresentam dificuldades de conhecimentos sobre PCR/RCR, principalmente, em relação aos conhecimentos científicos que devem orientar suas ações. As autoras op cit prosseguem afirmando que acadêmicos de enfermagem apresentam dificuldades de conhecimentos básicos sobre PCR/RCR e que levam essas dificuldades para o mercado de trabalho, desencadeando um distanciamento entre a teoria apreendida e a prática adquirida. Abre-se um espaço de reflexão sobre a metodologia de ensino utilizada, sugerindo o repensar da prática do ensino superior, revendo o perfil do profissional enfermeiro que se deseja formar.

Os discentes apontam claramente a dificuldade que têm em associar a teoria e a prática. Apenas 25\% (1) dos discentes saberiam fazer a manobra de reanimação cardíaca, se necessário. Enquanto que $75 \%$ (3) não saberiam. As escolas de Enfermagem no Brasil englobam em seus conteúdos poucos assuntos sobre Parada Cardiorrespiratória, sendo estes mais teóricos, já na atividade prática, este tema não é muito abordado, visto que, quando esses alunos se formam e se inserem no mercado de trabalho sentem-se pouco capacitados para atuarem em situações de emergência (SARDO e SASSO, 2008).

\section{Conclusão}

Ao atingirmos o objetivo deste estudo, concluímos que poucos discentes da Instituição pesquisada saberiam o que fazer diante de uma vítima de PCR, apesar de estarem próximos à conclusão do curso. Observamos que, apesar do conteúdo teórico e prático sobre PCR ser oferecido em algumas disciplinas, ao final do curso, os discentes ainda saem com essa lacuna em sua formação. Após o estudo, constatou-se a falta de habilidade quanto aos procedimentos realizados por boa parte dos discentes. Dessa maneira, reforça-se a necessidade de repensar a grade curricular do curso de Enfermagem, no que tange a carga horária das disciplinas que abordam a temática estudada.

A academia deve oferecer ao graduando de enfermagem um arsenal mínimo de conhecimentos para o atendimento a uma PCR, visando aperfeiçoar a execução de procedimentos emergenciais como compressões torácicas, desfibrilação e ventilação pulmonar. $\mathrm{O}$ futuro enfermeiro, ao sair da faculdade, deve estar apto a auxiliar e identificar problemas de saúde em situação de risco e fazer sucessivas reavaliações posteriores conforme as mudanças apresentadas no quadro do paciente, visando sempre rapidez e sincronismo com a equipe para uma melhor assistência prestar. 


\section{Referências}

1. BRASIL. Ministério da Saúde. Conselho Nacional de Saúde. Diretrizes e normas regulamentadoras de pesquisa envolvendo seres humanos, Brasília, DF, 1997. 106 p.

2. BRASIL. Ministério da Saúde. Regulamento Técnico dos Sistemas Estaduais de Urgência e Emergência. Ministério da Saúde (BR). Portaria $\mathrm{n}^{\circ}$. 2048/GM de 05 de nov. 2002.

3. CAPOVILLA. N. C. Ressuscitação cardiorrespiratória: uma análise do processo ensino/aprendizagem nas universidades públicas estaduais paulistas. Campinas; s.n; dez. 2002. 205f p. Tese: MestradoUniversidade Estadual de Campinas. Faculdade de Ciências Médicas. Departamento de Enfermagem, Campinas. 2002.

4. CRISTINA, J. A. et al. Vivências de uma equipe multiprofissional de atendimento pre-hospitalar móvel em suporte avançado de vida na assistência ao adulto em situação de parada cardiorrespiratória. Cienc. Enferm., Concepción, v. 14, n. 2, dic. 2008. Disponível em <http:// www.scielo.cl/scielo.php? $>$. acesso em 09 oct. 2011.

5. FERREIRA JUNIOR, D.A. Manobras de reanimação cardiorrespiratória no ensino Fundamental: uma proposta da Educação Física. Volta Redonda, 2010. 52f. Dissertação de Mestrado - Fundação Oswaldo Aranha. Centro universitário Volta Redonda - UNIFOA, Volta Redonda, 2010.

6. FIGUEIREDO, N. M. A. Método e metodologia na pesquisa científica. 3 ed. São Paulo: Yendis, 2008. 239 p.
7. ILCOR MEMBERS ORGANIZATIONS

Guidelines 2010 for Cardiopulmonary

Resuscitation and Emergency

Cardiovascular Care, Circulation 2010; 102 (suppl-I):86-171.

8. LIMA, S.G. de.; et AL. Educação Permanente em SBV e SAVC: Impacto no Conhecimento dos Profissionais de Enfermagem. Arq Brasileiro de Cardiologia 2009; 93(6) : 630-636

9. SARDO, P.M.G.; DAL SASSO, G.T.M. Aprendizagem baseada em problemas em ressuscitação cardiopulmonar: suporte básico de vida. Rev. esc. enferm. USP, São Paulo, v. 42, n. 4,Dec. 2008 . disponível em <http://www.scielo.br/ scielo.php?script $=$ sci_arttext\&pid $=\mathrm{S} 008$ $062342008000400023 \& \operatorname{lng}=$ en $\&$ nrm $=\mathrm{i}$ so>. Acesso em 09 Oct. 2011.

10. SASSO, G. T. M. D, SOUZA, M.L. A simulação assistida por computador: a convergência no processo de educarcuidar da enfermagem. Texto contexto Enferm, Florianópolis, 2006 Abr-Jun; 15(2):231-9.

11. SILVA, A. M.C da. et al - Avaliação do conhecimento sobre diagnóstico e tratamento da parada cardiorrespiratória entre estudantes de fisioterapia da universidade de Taubaté. Rev Bras Fisioter. 2010;14 (Supl 1): 316.

12. ZANINI, J; NASCIMENTO, E.R.P. do.; BARRA, A.C.C. Parada e Reanimação Cardiorrespiratória: Conhecimentos da Equipe de Enfermagem em Unidade de Terapia Intensiva. Revista Brasileira de Terapia Intensiva Vol. $18 \mathrm{~N}^{\circ}$ 2, Abril Junho, 2006.

Endereço para Correspondência:

Márcia Ribeiro Braz

marciabraz2009@gmail.com

Rua B, n 140, Jardim Belvedere

Volta Redonda - RJ

CEP: 27258-500 


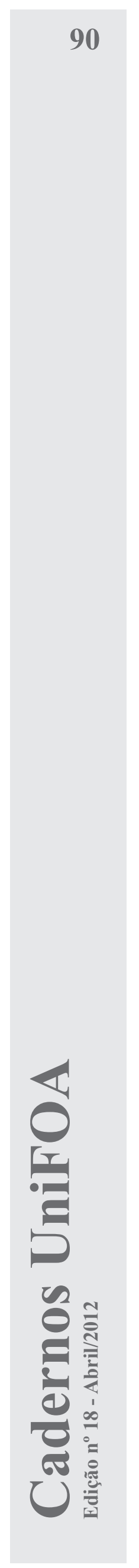

\section{Apêndice I}

1. Questionário

1- Você saberia como agir se encontrasse uma pessoa desacordada?

( ) $\operatorname{Sim}($ ) Não

2- Você sabe o que significa uma parada cardiorrespiratória?

( ) Sim ( ) Não ( ) Já ouvi falar, mas não sei o que é

3- Você sabe o que é reanimação cardiopulmonar?

( ) $\operatorname{Sim}($ ) Não

4- Caso tenha respondido Sim na questão $N^{\circ} 3$, saberia reconhecer os sinais de parada cardiorrespiratória?

( ) $\operatorname{Sim}($ ) Não

5- Você sabe para que serve o Desfibrilador elétrico automático?

( ) Sim ( ) Não ( ) Já ouvi falar, mas não sei o que é

6- Você saberia fazer a manobra de reanimação cardíaca se necessário?

( ) Sim ( ) Não

Fonte: Questionário adaptado de Ferreira Júnior 2010. 


\section{Apêncice III Termo De Consentimento Livre E Esclarecido (TCLE)}

Comitê de Ética em Pesquisa em Seres Humanos - CoEPS/UniFOA

Identificação do responsável pela execução da pesquisa:

Título do Projeto:

\section{CONHECIMENTO DE ACADÊMICOS DE ENFERMAGEM FRENTE À PARADA CARDIORRESPIRATÓRIA}

\section{Coordenador do Projeto: Dra. Márcia Ribeiro Braz}

Telefones de contato do Coordenador do Projeto: 21 - 97667803

Endereço do Comitê de Ética em Pesquisa: Av. Paulo Erlei Alves Abrantes, 1325 - Três Poços Cep.: 27240-560

Você está sendo convidado (a) a participar da pesquisa “CONHECIMENTO DE ACADÊMICOS DE ENFERMAGEM FRENTE À PARADA CARDIORRESPIRATÓRIA”. Se decidir participar dela, é importante que leia estas informações sobre o estudo e o seu papel nesta pesquisa. Os objetivos deste estudo são: identificar o conhecimento de acadêmicos de enfermagem sobre a atuação do enfermeiro na parada cardiorrespiratória e descrever os sentimentos despertados nestes acadêmicos, frente à vítima de parada cardiorrespiratória.

Você poderá se recusar a participar da pesquisa e poderá abandonar o procedimento em qualquer momento, sem nenhuma penalização ou prejuízo. Durante a entrevista ou o preenchimento do questionário, você poderá recusar a responder qualquer pergunta que por ventura lhe causar algum constrangimento. A sua participação como voluntário, não lhe conceberá nenhum privilégio, seja ele de caráter financeiro ou de qualquer natureza, podendo se retirar do projeto em qualquer momento sem prejuízo a V.Sa.

A sua participação poderá envolver o seguinte risco: perda do sigilo de sua identidade, para evitar que isso aconteça com facilidade, as pesquisadoras utilizarão codinomes para cada participante do estudo. Serão garantidos o sigilo e privacidade, sendo reservado ao participante o direito de omissão de sua identificação ou de dados que possam comprometê-lo. Na apresentação dos resultados não serão citados os nomes dos participantes.

Confirmo ter conhecimento do conteúdo deste termo. A minha assinatura abaixo indica que concordo em participar desta pesquisa e por isso dou meu consentimento.

Petrópolis, de de 2011 